NBER WORKING PAPER SERIES

\title{
A RENAISSANCE INSTRUMENT TO SUPPORT NONPROFITS: THE SALE OF PRIVATE CHAPELS IN FLORENTINE CHURCHES
}

\author{
Jonathan Katz Nelson \\ Richard J. Zeckhauser \\ Working Paper 9173 \\ http://www.nber.org/papers/w9173 \\ NATIONAL BUREAU OF ECONOMIC RESEARCH \\ 1050 Massachusetts Avenue \\ Cambridge, MA 02138 \\ September 2002
}

The views expressed herein are those of the authors and not necessarily those of the National Bureau of Economic Research.

(C) 2002 by Jonathan Katz Nelson and Richard J. Zeckhauser. All rights reserved. Short sections of text, not to exceed two paragraphs, may be quoted without explicit permission provided that full credit, including (C) notice, is given to the source. 
A Renaissance Instrument to Support Nonprofits: The Sale of Private Chapels in Florentine Churches

Jonathan Katz Nelson and Richard J. Zeckhauser

NBER Working Paper No. 9173

September 2002

JEL. No. L31, D82, D64

\begin{abstract}
Catholic churches in Renaissance Florence supported themselves overwhelmingly from the contributions of wealthy citizens. The sale of private chapels within churches to individuals was a significant source of church funds, and facilitated a church construction boom.

Chapel sales offered three benefits to churches: prices were usually far above cost; donor/purchasers purchased masses and other tie-in services; and they added to the magnificence of the church because donors were required to decorate chapels expensively.

Donors purchased chapels for two primary reasons: to facilitate services for themselves and their families, such as masses and church burials, that would speed their departure from Purgatory; and to gain status in the community. Chapels were private property within churches, but were only occasionally used directly by their owners. The expense of chapels and their decorations made them an ideal signal for wealth, particularly since sumptuary laws limited most displays of wealth.

To overcome the contributions free-rider problem, these churches sold private benefits not readily available elsewhere, namely status and salvation.

Jonathan Katz Nelson

Syracuse University in Florence

Piazza Savonarola, 15

Florence, Italy 50132

Richard J. Zeckhauser

Kennedy School of Government

Harvard University

79 JFK St.

Cambridge, MA 02138

and NBER

richard_zeckhauser@harvard.edu
\end{abstract}


Forthcoming in The Governance of Not-for-Profit Firms, Edward Glaeser (ed.), Chicago: University of Chicago Press.

March 21, 2002

\title{
A Renaissance Instrument to Support Nonprofits: The Sale of Private Chapels in Florentine Churches
}

\author{
Jonathan Katz Nelson \\ Richard J. Zeckhauser ${ }^{1}$
}

\section{Introduction}

The United States has long been "the land of nonprofits." When Alexis de Tocqueville visited in 1831-32, he noted America's distinctively widespread and successful use of voluntary associations (de Tocqueville 1835). ${ }^{2}$ In recent decades, secular nonprofits in the United States have grown dramatically in size and importance. But the nonprofit as a crucial player in society is neither an exclusively modern nor predominantly American phenomenon, and many nonprofits have a religious base. Our paper considers the operation of a historic, non-American, religious-based nonprofit: the Roman Catholic Church. The most important nonprofit in Renaissance Florence, the Church had two clear objectives: to address the needs of the parishioners, and to build churches in order to propagate the faith. To meet these objectives and to grow as an institution, the Church needed substantial private support from donors.It sold private chapels within churches were sold to get such support, and these sales brought in significant tie-in revenues from burials, funerals, and commissioned masses. The monies supported the construction, expansion, and renovation of churches, and the religious services celebrated in the chapels provided employment for many priests and members of religious orders. Those who provided financial support enjoyed the satisfaction of contributing to noble and spiritual endeavors. But they also reaped considerable private benefits, notably status, 
permanent recognition, and expectations of salvation. The Church thus sold benefits to donors to raise private funds, and transformed the private funds into public goods.

This "transformation" of contributions from wealthy merchants and bankers involved the production of art. In Renaissance Florence, the Church played a major role in stimulating the visual arts, architecture, and music, though this was not the mission of this institution. (Support of the arts is often a role of modern nonprofits, but the history of the Church demonstrates how faith-based organizations can deliver public services in this area.) Most visitors to Florence today assume that the extraordinary examples of religious art and architecture were commissioned by the local church, and that each church was largely controlled by the Vatican. In fact, most church art was privately commissioned and privately owned, and the local churches had a large degree of local autonomy. Even the chapels themselves, which contained most of the art, remained private property until modern times. The sale, decoration, and staffing of private chapels played a fundamental role in the fundraising and financing of local churches in Renaissance Florence. The art produced benefited not only the donors, but also the general public and the Church. Most Florentines believed that works of art contributed to the glorification of God, the dignity of the Church, and the status of the city.

This paper focuses on Florentine churches over about 250 years. This period begins about 1280, when construction began on the first two churches to contain significant numbers of private chapels, the late Medieval basilicas of Santa Croce and Santa Maria Novella. It ends in the early 1530s, when Renaissance Florence became a duchy, and the Medici family began to exercise much greater control over local churches, and specifically on the sale and decoration of private chapels. Sections II, III, IV, and V address the historical context of our analysis. Section II looks at the similarities between the functions and needs of modern nonprofits and the 
Renaissance Church, and how the selling of chapels provided a useful way to raise money. Section III discusses the currency and prices of Renaissance Florence, and the reasons for our chronological and geographic focus. Section IV discusses the layout of Renaissance churches, including a description of private chapels, and the construction of these spaces. Section V explores funding, especially for construction costs, with special attention to the sale of private chapels.

Sections VI and VII consider why churches offered such spaces for sale, and why donors bought them. Section VI addresses the supply side of chapels, reviewing the experience of three major churches. It argues that local churches supplied private chapels because the benefits they received -- the direct payments for the chapels, tie-in revenues, and enhancements to the church - substantially outweighed the costs. Section VII looks at the demand for chapels. Why were donors willing to pay significant amounts to obtain and decorate private chapels, and to pay for masses in these spaces? It argues that the demand arose because the donors could buy benefits not available elsewhere, primarily salvation and status. (Similarly, the donation of a building to a university both establishes a form of immortality for one's name and enhances one's status.) Section VIII consists of some short concluding remarks.

\section{Renaissance and Modern Nonprofits}

1. The Renaissance Church as a nonprofit. Lester Salamon noted that all nonprofits share six characteristics: they are organized, private, self-governing, voluntary, public benefit in nature, and they do not distribute any surplus or profits (Salamon 1999, 10-11). Clearly, the Renaissance Church in Italy was a highly organized and self-governing institution. It can, on the whole, be considered voluntary: though virtually all Italians were Roman Catholics, and Church regulations 
demanded participation in certain activities, most people rarely attended mass. The Church also fits the "functional definition" of nonprofits, that they work in the public interest or for public purposes. ${ }^{3}$ In Renaissance Italy, it offered several essential services that the local government could not or would not provide: education for children, charity for the poor, medical assistance for the sick, and of course meeting spiritual needs.

In theory, there were severe non-distribution constraints within the Renaissance Church: ${ }^{4}$ the abbot of a monastery, for example, could not simply pocket surplus revenue. Nevertheless, the power of the Church and the high degree of local authority led to widespread abuses. Perhaps the most infamous example is one that stirred protests by Martin Luther in the early $1500 \mathrm{~s}$. After the Archbishop of Magdeburg, Germany, raised considerable funds through the sale of indulgences, he sent half to Rome for the construction of the church of St. Peter's, and kept half to pay off his debt with the local banking family. Among local churches in Florence, however, the profit derived from the sale of chapels and masses was used primarily to construct, maintain, and staff the building.

2. Free-riders and private beneficiaries. The most critical challenge to many nonprofits, regardless of era or locale, is to secure financial support. Nonprofits that provide subsidized benefits to the community, but receive insufficient government funding to provide them, need support from private parties. Rarely will altruistic concerns be sufficiently powerful to ensure the needed funding. As Mancur Olson (1965) demonstrated in The Logic of Collective Action, voluntary organizations (those that lack coercive powers to tax) confront serious free-rider problems. Few individuals will provide substantial support to a truly collective undertaking; all will seek to capitalize on the contributions of others. 
Olson perused the American landscape, and found that successful nonprofit organizations had found a clever solution. They provided private benefits that are not readily available elsewhere in exchange for contributions. For example, the American Medical Association, once very powerful, could charge stiff dues because it provided its members with a valuable referral network. Similarly, as we shall see, the churches of Renaissance Florence provided individuals with salvation aids -- private masses, indulgences, and intramural burial spaces -- in exchange for contributions.

Olson also briefly observed that individuals donate to charity "because of a desire for respectability or praise." We provide strong evidence that such status-seeking motivated church contributions in late Medieval and early modern Italy. In particular, it motivated major donations to purchase chapels and significant expenditures to decorate them. Whether in Renaissance Florence or modern America, nonprofits capitalize on their distinctive capability to convey status. They publicly associate the donor with other distinguished individuals and families, and provide a socially acceptable way to signal one's wealth. ${ }^{5}$

3. Profits from the Provision of Private Benefits. To sell at a high markup, nonprofits must focus on goods and services where they have market power. Modern churches that own regular businesses can at best charge a modest "feel good" premium beyond market price. Big premiums require major advantages in the market. Many wealthy churches accumulate their wealth by providing the hope for a better afterlife in exchange for contributions. The most successful in this domain, such as the Mormon church, which requires tithing to stay in good stead, are often very explicit about possible states for one's eternal life. 
What net profit does a nonprofit receive when it provides a private benefit in exchange for a contribution? Its net is the whole contribution less fundraising costs and the costs of providing benefits to donors. Most Renaissance churches offered private masses, which could reduce the time that donors would spend in Purgatory. These services required private masses, which led to the need for priests to conduct them.

Physical structures offer a different story. Contemporary universities tend to sell buildings at or sometimes below cost. However, they often sell rooms and spaces within them as well. Such double sales afford the potential for profit. The amount of profit depends significantly upon how essential the building is for the nonprofit. A needed dorm essentially reaps a 100 percent surplus from any donations; the university would have built the structure even if it did not receive outside funds. But if the new building will house some little-used museum, say, even a contribution of the full construction cost may entail a loss, since the land will likely be given for free, and maintenance will be required.

We demonstrate that chapels provided a wonderful way to finance the Renaissance church. First, the monopoly on afterlife benefits allowed churches to sell their goods and services -- chapels and masses -- at prices well above cost. Second, though chapels were sold to private parties, donors were rarely physically present in their chapels. These individuals selected and paid for the expensive decorations within chapels, and both the art and architecture added significantly to the magnificence of churches. Third, the church, like the modern university selling buildings, could boost prices due to the status benefits donors received. 
The benefits to a church from the sale of a private chapel can be summarized as follows:

$$
\begin{aligned}
\text { Benefits } & =\text { [price of chapel }- \text { cost of chapel }] \\
& + \text { value of benefits from tie-in sales } \\
& + \text { value to church of decorated chapel }
\end{aligned}
$$

The last term is what the church itself would have paid to secure the decorated chapel if no one would donate it. Our analysis shows that chapels generally sold at prices far above cost; the term in brackets was solidly positive. The two additional terms made the proposition of selling private chapels even more attractive.

4. Residual claimants. One characteristic feature of for-profit organizations is a clear residual claimant, namely the shareholders. This implies that all parts of the organization are working toward a common purpose. In many contemporary nonprofits, it is not clear who is the residual claimant. Theoretically, it would be the board, but they are not allowed to take any surplus. It might be posited that the board's preferences will guide the allocation of the surplus, but directors of the same nonprofit may have vastly different ideas of what the organization should do. Interestingly, the intended residual claimants in monastic churches were the religious orders, whose members had taken vows of poverty. They could not accept sums of money beyond living expenses, but they could accept prestigious buildings and beautiful decorations. These made their lives more pleasant, raised the respect of their profession, and, by adding to the glorification of God, contributed to one of the stated goals of the nonprofit to which they had dedicated their lives..

Lay people usually dominated the building committees of Medieval and Renaissance churches, and thus they often made key decisions on chapel sales. This was 
the situation in the church of Santo Spirito, where the building committee did not maximize revenues from the sale of chapels. Rather, it set low prices for some of the most prestigious chapels, which were purchased by members of the building committee. It is not clear to what extent this was self-dealing, as opposed to representing rewards for past and contemplated future contributions.

5. Focus on posterity and mission drift. Nonprofit organizations can last much longer than the human life span. Harvard University has passed the 350-year mark, and the Catholic Church is into its third millennium. Conspicuous association with such an institution -- say by paying for a named and long-lived physical structure it uses -provides a form of immortality. Such immortality is not achievable through either family or personal possessions, which change their names and ownership. How can a nonprofit assure current donors that the assets promised in return for their contribution will not be taken back in the future? Part of the answer is that since the nonprofit must continue to raise new funds, current management has to show fidelity to past donors; drawing down an endowment or allowing physical structures to languish can sound a death knell for a nonprofit.

Nevertheless, nonprofits can compromise their mission if they have a strong fundraising orientation, especially one that relies heavily on the sale of private benefits. An organization may shifts its goals in order to attract donors and funds. Fundraising performance often becomes a prime marker of the success of the organization's leader, which further shifts his activities. In addition, donors may gain some control over the organization, and influence its direction. The original objectives of the organization then receive relatively less emphasis, and new goals emerge. With time, the mission of the organization tends to drift. 
The history of the Catholic Church helps illustrate these dangers. In the late Medieval period, it began to sell private benefits in order to support itself, and then to grow in numbers of physical structures and personnel. The activities surrounding these sales noticeably influenced the behavior of the individual churches involved. To support their staffs, many churches became virtual mass and funeral factories for a small number of wealthy benefactors. Partially as a reaction against these abuses, the Vatican in the late sixteenth century took an increasing active role in regulating the sale of privately-owned chapels. By the nineteenth century private ownership of chapels had virtually disappeared, though private burial areas in churches can still be purchased today. ${ }^{6}$ The Church, like other nonprofits, must balance its focus on posterity, and thus its fundraising activities, with efforts to limit the drift of its original mission.

\section{Measures for and Focus of the Analysis}

1. Prices and currency. Most studies of Renaissance art and architecture provide prices in florins only, but these figures are difficult to compare, given the ever-increasing value of the florin in the Renaissance, and they are even harder to relate to our own times. ${ }^{7}$ Following the example of Richard Goldthwaite, we compare prices to the rate of pay for unskilled construction workers, which remained extremely stable at roughly $1 / 2$ lira per day from 1350 to 1527 . A full-time laborer could hope to work at most about 270 days a year, given the large number of religious holidays. Goldthwaite (1980) estimated that during the entire period under consideration one "man-year" of unskilled labor was worth about 150 lire; the total yearly cost to provide one adult with essentials was 55 to 75 lire. $^{8}$

2. Chronological and geographic limits. We focus on Florence from about 1280 through the 1530 s, for three reasons. First is the extraordinary reputation enjoyed then and now by the art and 
architecture produced in late Medieval and Renaissance Florence. The Church not only employed and encouraged the patronage of major artists, but also played a crucial role in the preservation of their work. Most surviving Renaissance works were made for private chapels in churches, and many of these objects and structures are now owned or protected by modern nonprofits.

A second reason to focus on Florence is the unusually rich quantity, quality, and variety of surviving documentation. The best known original source are the records of the Catasto; these and related financial records were made on several occasions in the 1400s and beyond. Other significant documents include the private account books kept by merchants, a type of financial record particularly popular in Florence, and the account books and memorials kept by churches. Though this treasure trove of documentary material is exceptional for a major Renaissance city in Europe, it is highly fragmentary in comparison with the material available for modern economic studies.

As a result of the abundant source material, there are far more studies on the history and society of medieval and Renaissance Florence than on any other Italian city. The research of five scholars has been particularly important for this paper: Richard Goldthwaite $(1968,1980,1993)$ on the construction industry, banks, and private wealth; Sharon Strocchia (1992) on Tuscan funerary rituals; and Samuel Cohn $(1988,1992)$ on wills in Tuscany. ${ }^{9}$ In addition, the Ph.D. dissertations by Annegret Höger (1976) and Ena Giurescu (1997) offer crucial information on the origins of private chapels in Florence. Remarkably, given the plethora of research and publications on Renaissance architecture, no study has established a complete financial record of the total expenses and funding sources for the construction of a church. Very few sustained studies address the phenomenon of private chapels over the course of our period. ${ }^{10}$ 
A third motivation for our geographic focus is that private citizens played a particularly large role in the economy and government of late medieval and Renaissance Florence. Bankers and merchants paid for the vast majority of the church decorations, and made substantial contributions toward the construction of churches. Perhaps in no other city were so many churches remodeled or rebuilt in order to accommodate private chapels. The economic sophistication of the Florentines, their abundance of liquid wealth, and their business leaders' need to display their status all contributed to the success and refinement of this fundraising instrument for the leading Renaissance nonprofit (Goldthwaite 1993). The direct funding of the Renaissance Church in Florence by private individual and family donors provides a useful parallel to modern American nonprofits.

\section{The Organization and Construction of Churches}

1. Definitions. Since the Middle Ages, every major city in Europe has had a cathedral, the principal church of the diocese, which contained the cathedra or throne of the bishop, and several parish churches under the bishop's direct supervision. ${ }^{11}$ In addition, vast numbers of monastic churches were built in this period; these constitute most of the examples in our study. Monastic churches were open to the general public but designed to meet the needs of the religious community that lived in the adjacent monastery or convent. Nearly all were basilicas; that is, they had an oblong plan and longitudinal axis, usually consisting of a central nave and side aisles. Transept arms extended from both sides of the main chapel or high altar, both located at the end of the nave (figures 1,3). Two significant architectural features in monastic churches were the choir, an enclosed structure usually located in front of the high altar, where the members of the order prayed and sang, and the rood screen, which bisected the nave, keeping 
women in the area further from the high altar. ${ }^{12}$ The "religious" were the members of the orders - the friars, nuns, monks, and canons. Most male religious were not priests, so they could participate in but not officiate at mass. The most prominent orders throughout Europe, including Tuscany, were the Franciscans and Dominicans. Both were mendicant orders; their rule embraced collective poverty. The friars had no personal property, and thus they had to seek donations to support themselves, their churches, and their mission goals.

2. Private chapels. During our period, the term "chapel" referred to any area where mass was conducted, and was virtually synonymous with altar. Altar tables were attached to the side and entrance walls of churches, to columns, and even to rood screens. In this paper, however, we usually use chapel in the modern sense, to refer to a discrete architectural area, with the altar table opposite the entrance. A chapel could be a spatial box defined by three walls, with the fourth side originally closed off by a metal gate, as in the churches of Santa Maria Novella and Santa Croce (figures 1-5), or a shallow niche, as in the church of Santo Spirito (figures 6-7). In most churches such spatial boxes were built in both arms of the transept; in many churches, such as San Lorenzo, chapels of this type also lined the side aisles.

Most chapels and wall altars were private property. The main exceptions in Florence were the Cathedral, which did not have private chapels, and the high chapels in some monastic churches, which remained the property of the religious orders. The rights to private chapels were sold most often to individuals or families, including brothers and extended clans, but at times to groups such as lay brotherhoods or trade associations. ${ }^{13}$ The main function of chapels was as a setting for memorial masses, not a place for individuals to attend mass. In addition, many private chapels provided burial places for donors and their families. 
In Florence, the first churches with significant numbers of private chapels are in two basilicas built for the leading mendicant orders, which were both rebuilt in the late 1200 s and early 1300s. The Dominican church of Santa Maria Novella has four spatial box chapels in the transept (figures 1-2), and the slightly later Franciscan church of Santa Croce has ten (figures 3 5). In the later middle ages, the new class of extremely wealthy and status-conscious merchants created a strong demand for private chapels. By the late 1300s, these chapels had became popular across Europe, especially in affluent commercial cities such as Florence, and they line the walls of most late Medieval and Renaissance churches.

The sale of private chapels strongly affected church architecture. In fifteenth-century Florence, architects created plans that allowed for more of these privately-owned spaces (see Saalman 1993; Goldthwaite 1993, 122-23). In San Lorenzo and Santo Spirito, for example, Brunelleschi abandoned the tradition of wall altars along the aisles and made plans for a series of spatial chapels (figures 6-7). The advantages of this arrangement were sufficiently great that other churches, including Cestello, were remodeled, and the designs for new churches provided for spatial chapels along the side walls (figure 8).

For most practical purposes, these chapels were private property, and identified as such by conspicuous inscriptions, coats of arms, and banners. Chapels were purchased, left to heirs, and in many cases resold. Other than priests, few people ever entered these spaces. Since the spatial box chapels were located in the transept, beyond the rood screen, they were off limits to women, and men would have found them locked with gates. From a distance, visitors could appreciate the architecture and decorations in private chapels. However, the main images of many altarpieces were covered by curtains or shutters. ${ }^{14}$ The paintings would be visible on special occasions, such as feast days or when masses were held at these altars. 
Prestigious chapels were expensive. In the late 1400s, Piero del Tovaglia reasoned, "If I spend 2,000 florins on my townhouse (palazzo), my dwelling on earth, then 500 devoted to my residence in the next life seem to me money well spent." This wealthy Florentine evidently planned on spending 500 florins for his private chapel and tomb (Kent 1995, 183). The purchase price of a private chapel constituted only a part of the total cost, often less than half. The related tie-in expenses were furnishing the chapel with an altar and required liturgical instruments, decorating the space, and providing funds for priests to say masses. In the late 1400s, Filippo Strozzi, spent 300 florins (16 man-years) on a chapel in Santa Maria Novella -- the standard price for a private chapel in a main church -- and over 900 (48 man-years) on the decorations and the tomb within (Sale 1976). (The Strozzi chapel is in the right transept, adjacent to the main chapel; figure 1). The magnificence of the church benefited from such furnishings and decorations, and the coffers of the church benefited directly from the payment for masses. ${ }^{15}$ These additional responsibilities constitute one significant difference between chapels and traditional private property. If owners failed in these obligations, they could lose the right to the chapels, as happened repeatedly in various churches during our period. A second unusual characteristic of chapels as private property is that their owners rarely visited them. Most donors probably went only a few times a year.

As context for these figures, in 1427, tax (Catasto) officials established the expected maintenance cost of a single adult at 14 florins, just under half of one man-year. ${ }^{16}$ The yearly income of higher government officials in the fifteenth century was 100-150 florins, and that of a manager in a merchant-banking house was 100-200 florins. Many of the patrons discussed in this paper were extremely affluent, with a personal wealth declared in Catasto records at between 5,000 and 10,000 florins. In 1427, Cosimo de' Medici was worth 100,000 florins (3,137 man- 
years). Other financial records reveal that the personal assets of some prominent donors were considerably higher: Niccolò di Jacopo Alberti was worth 340,000 florins (10,741 years) in 1377, and Filippo Strozzi was worth 116,000 florins (6,138 man-years) in $1491 .{ }^{17}$

3. Church Construction Boom. Florence witnessed an explosion in the number and size of its churches in our period. This development was not a response to demographic expansion. Even by the mid-1500s, the population had not regained its level of 1348 when the Black Death wiped out between half and two-thirds of the residents. Nevertheless, the number of churches had dramatically increased, and many of the older buildings had been extensively restored. The quantity of these monuments, the modern style of their architecture, and the quality of the art they contained, were not necessary for the traditional functions of the Church: masses, confession, charity, and education. However, the construction boom brought several advantages to the priests and religious in local churches. The new or renovated buildings enhanced the prestige of the Church and religious orders, and they attracted considerable additional funds that permitted an increase in the number of the priests and religious, and the quality of their lives. 4. Public Goods from Church Construction. Most Florentines believed that the construction or major renovation of a church brought two major public goods. First, churches glorified God, the Virgin, and the Saints -- a larger, more beautiful building was interpreted as expressing greater praise to these holy figures, a benefit to all residents in the city. Within the religious orders, this view had to be balanced against the ideals of austerity and simplicity, especially those championed by St. Francis. For his followers, indeed for all Christians, the primary justification for such buildings and their decoration was the glorification of God. New and renovated churches added to a city's beauty and reputation, another public good for its residents. This view was often expressed both explicitly and implicitly by Medieval and Renaissance sources. This 
was a period of extraordinary competition between neighboring Italian city-states, such as Florence, Siena, and Pisa. This atmosphere encouraged governments and citizens to praise their cities in public and private. A wide range of surviving documents, from formal decrees and academic discourse to travel books and private journals, describe the beauty and justify the reputation of cities by celebrating their major architectural monuments, especially each city's Cathedral and most prominent churches.

Some of the public goods attributed to local churches benefited a defined population, and might be thought of as "bounded" public goods. In a modern society, this term could apply to a public park in the suburbs, which overwhelmingly helps local residents, though outsiders may use it occasionally. In our period, the residents of Florence and most other large European cities had an extremely developed sense of belonging to particular neighborhoods (Eckstein 1995). Florence was divided into four quarters, each of which was partitioned into districts. The construction or renovation of a local church would add to the beauty of the entire city, but would especially improve the status of a particular neighborhood. In addition, Medieval and Renaissance accounts often refer to churches and the art within as fulfilling an obligation to holy figures, and expressed the hope that such commissions would bring more benefits. These obligations and hopes were felt most strongly by those who worshiped in the new or renovated church.

5. Construction Costs. The single largest expense for local churches was construction costs for the church and related buildings. Other major expenses fall into three main categories: church decoration, including stained glass windows, frescoes, statues, and altarpieces; staff living expenses for the religious, including room, board, and clothing; and religious functions, including liturgical objects, special vestments, and candle wax. Local churches employed 
architects and workers to construct buildings or chapels. Private individuals rarely paid for these expenses directly but they did hire artists to decorate private chapels, and they purchased the many objects needed for masses at private altars.

Partial construction costs for several fifteen-century churches in Florence have been collected and analyzed by Goldthwaite. The most complete data are for Santo Spirito, largely rebuilt between 1477 and 1491 (figures 6-7). For these years, the detailed account books itemize construction costs of 83,172 lire (554 man-years) for the main church. In 1449-50, the much smaller church of San Pancrazio was said to cost 5,500 florins (176 man-years). ${ }^{18}$ For the medium-sized church of San Salvatore, the merchant Castello Quaratesi bequeathed 14,000 florins (523 man-years) in 1465, but when the building was completed at the end of the century, the private chapels were then sold to raise additional funds. ${ }^{19}$

6. Chapel costs. Original documents and modern authors often indicate the price of chapels, or the amount of money left in wills for these spaces, but the cost of actually building chapels is rarely discussed, and is extremely difficult to determine. Since some churches had considerable market power in chapel sales, the gap between price and cost might be great.

One extremely valuable source is the account book for the church of Cestello (Luchs 1977; figure 8). In the early 1480s, this church was built with uninterrupted nave walls which led to the only chapel, the high altar. In 1488 , plans were made to add eight new chapels in the nave, four on each side. To build them, the side walls had to be pierced and new spatial box chapels added, a process much more costly than building chapels in a new church. The Cestello patrons paid 50 to 70 florins (2.2 - 3.1 man-years) for their chapels, about a quarter of the price of chapels at Santo Spirito at the time. Only the Cestello sums correspond to actual building costs. Most of its chapels cost between 50 and 60 florins to build for the walls only, excluding the 
window, altar table, and decorations. ${ }^{20}$ Documents for San Lorenzo also provide some information on chapel costs. Here the nave was build to include side chapels; between 1463 and 1465, patrons paid 125 florins (5.5 man-years) each to the masons responsible for building the church. This figure probably includes at least some of the cost of the side aisles, and perhaps of the central nave as well.

7. Construction decisions. Only the Vatican could grant approval for construction of all chapels, and thus for the creation or transformation of local churches. This meant that all major proposals needed powerful political and religious backers, and generous payments to numerous members of the ecclesiastical hierarchy were common. Approval, however, did not translate into financial support or a tax. In a typical arrangement, a religious order was offered a piece of publicly owned or private land, together with some funds for construction. Over a long period, the religious raised additional monies to build. The difficulty of this enterprise helps explain why the construction of major churches often took a century or longer. ${ }^{21}$

The role of the Vatican should not be overstated; the Roman Catholic Church was less centralized in the Medieval and Renaissance periods than after the Council of Trent in the 1560s. Even after that date, the Vatican had a more modest role than today in directing local churches. In the period under study, local churches were run by priors or abbots, named (or at least approved) by the local bishops. Priors made most decisions regarding day-to-day operations of the church, but major decisions were subject to approval by Rome. ${ }^{22}$ The decision to construct, expand, or renovate a church could be made in many ways, and for a wide variety of reasons. Surviving evidence indicates a very fluid situation that was not regulated by any single procedure or governing body. Proposals could be advanced from a city government, ruling family, wealthy merchant, or religious order. 
In late Medieval and Renaissance Italy, the management of construction projects, including new churches, was usually directed by the opera, the "board of works" or "building

committee. ${ }^{23}$ The operai, or committee members, were responsible for all major decisions concerning the new structure: they raised and distributed funds, selected the architect, approved plans and subsequent alterations, authorized contracts, hired laborers, and purchased materials. They could determine costs and prices of chapels, though sales had to be approved by ecclesiastical officials. Though members of religious orders might serve on a building committee, this institution was dominated by laymen, usually wealthy, respected figures from the local community. Within the city of Florence, most of the powerful church officials, influential building committee members, and principal donors to churches belonged to only a few clans. This was particularly true of monastic churches, since each prominent family would often support and send a family member to a particular religious order. When negotiations were conducted by churchmen and committee members who belonged to the same or allied families, interests often coincided nicely.

\section{Funding Church Construction}

There were three potential sources for the funding of Florentine churches: the government; the Church, i.e., the Vatican and religious orders; and individual donors. We now consider what each group contributed for what and when.

1. Government Funding. In the 1400s, the construction of most Florentine churches was supported by private donations, usually in exchange for chapels, and not by contributions from the government, Vatican, or religious orders. As a result, government funding does not play a significant role in our model of how the Renaissance Church transformed private funds into 
public goods. As we shall see, however, government grants seem to have served as "seed money" for the construction of several Medieval churches, which then turned to the private sector for additional support. Before 1400, substantial government funds had been given to the three most prominent new churches in Florence -- the Cathedral, Santa Maria Novella, and Santa Croce -- and the commune had plans to finance the church of Santo Spirito ${ }^{24}$ Santa Maria Novella and Santa Croce, both built in the late 1200s for new mendicant orders, were the first churches in Florence to contain significant numbers of private chapels. ${ }^{25}$ According to Giurescu (1997), the contributions given by the commune of Florence, together with some unrestricted private donations, covered the basic construction costs of both churches. Despite such support, both churches relied heavily on funds raised through the sale of chapels and their accompaniments.

2. Vatican and Religious Orders. The main financial support from the popes and cardinals for church construction and renovation provided for the basilicas under the direct control of the Vatican and the titular churches of individual cardinals. In the 1200s and early 1300s, the Vatican played a major role in encouraging the new mendicant orders, and contributed to the building and decoration of their churches. In later periods, however, the Vatican and the religious orders usually viewed local churches as sources of income, not as recipients for their largesse. Tithes, for example, were collected at the local level, but they were not given to local churches. Most of these funds remained with the local ecclesiastical officials, who would give a percentage to the Vatican, and to the individuals or organizations that actually collected the tithes, such as the Medici bank.

3. Private Donations and Indulgences. Beginning in the mid-1200s, a series of Vatican regulations provided crucial support for local churches. These bulls allowed for the burial of 
laymen within the walls of the churches and for the sale of indulgences. With the invention of Purgatory in the late medieval period, Christians learned that the souls of most people would reach heaven only after spending an extended period in this transitional area. Priests could absolve the guilt of sinners, but they still had to repay their debt to God by suffering punishment. According to the theory of indulgences, the period of punishment could be reduced by various types of good deeds, including donations. In the late 1400s, for example, Cardinal Albert of Brandenburg calculated that the indulgences he had obtained for himself could reduce his stay in Purgatory by $39,245,120$ years.

The fundraising opportunities offered by the sale of indulgences attracted many church officials. One possibility was to sell written indulgences to those who visited the church. In Florence, it was more popular to offer indulgences at no cost to visitors on certain days, guaranteeing high attendance. For example, a papal bull of 1344 informed the faithful that they could reduce their stay in Purgatory by 515 days by attending mass on Thomas' feast day at Santa Maria Novella (Giurescu 1997, 207). The indulgences given for attending masses in specific chapels naturally raised the prestige of those spaces; this encouraged contributions by private individuals to purchase and decorate such chapels.

The most direct way to gain indulgences was to donate cash or property. In 1476, Pope Sixtus IV sold indulgences that benefited the souls of the dead to raise funds for the reconstruction of St. Peter's in Rome. The mendicant friars, who took vows of personal poverty, were well suited to warn moneylenders and traders about the punishments awaiting those with ill-gotten riches, and to encourage them to make substantial donations. A series of bulls from the 1200s gave the Dominican and Franciscan friars in Florence the authority to accept funds in exchange for reducing the punishment for usury (Giurescu 1997, 2-3). This practice, however, 
was not always accepted. Saint Antoninus, the Archbishop of Florence in the mid-1400s, objected to this type of barter for salvation. (Even today, the question of what constitutes an acceptable quid pro quo for donations is often an issue with nonprofits, and Antoninus' concerns fall in this category. ${ }^{26}$ )

The desire to reduce one's time in Purgatory surely encouraged some of the generous unrestricted grants left to Santa Maria Novella and Santa Croce. Giurescu states that these funds, combined with the substantial contributions from the commune of Florence, paid for the construction of the main body of both Santa Maria Novella and Santa Croce (figures 1-5). This includes the nave and transept, the latter with rows of chapels. Regulations about indulgences and burial encouraged private donations to churches across Europe. In his study of nearly 3,400 wills drawn up between 1276 to 1425 in six central Italian cities, Cohn (1992) documented a major change in the years following the plague of 1362-1363 (and not immediately after Black Death in 1348, as generally expected). In the earlier period, he found a large number of small, unrestricted grants to churches or other institutions, such as hospitals. Testators rarely asked the institutions for anything in return. In the later period, Cohn found a smaller number of far larger gifts, and these grants were usually restricted. As part of the growing "cult of remembrance," testators arranged their bequests to obtain burial rights, private chapels, and commemorative masses.

\section{The Supply Side: Benefits to Churches from the Sale of Chapels and from Tie-In Sales}

1. Sale of Chapels. Our principal argument is that churches were eager to sell private chapels as part of their fundraising strategy. Such sales produced significant additional benefits because donors also had to pay for other goods and services, such as chapel decoration and masses. The 
churches also received the benefit of more magnificent structures, both in scale and in decoration. Basically, what the churches received far exceeded any costs of provision. Though magnificent churches provided benefits to the neighborhoods and the worshippers, the biggest beneficiaries from the chapel sales were the priests and members of religious orders associated with the individual churches. They were able to work in beautiful surroundings, participate in a vibrant and growing institution, and secure employment. ${ }^{27}$ We begin our discussion of supply by considering chapel sales at three major churches.

a. Santa Maria Novella and Santa Croce. By the 1330s, the friars at both Santa Maria Novella and Santa Croce had sold the patronage rights to most of the original transept chapels. In exchange for the purchase of a chapel, and the commitment to outfit and decorate it, a donor received the chapel together with a stipulated number of perpetual masses in the chapel and the right to burial there. This exchange established a pattern for raising funds that was imitated in virtually all Florentine churches for the rest of our period and beyond. The history and reasons behind the friars' dramatic and influential decision to sell chapels are rarely discussed, and few documents clarify these crucial points. According to Giurescu, the mendicant orders sought funds from the wealthy merchants of Florence only after the completion of the transept and nave of Santa Maria Novella and Santa Croce. But one previous document suggests a very different scenario.

In his testament of 1292, the banker Donato Peruzzi left 200 lire (9.3 man-years) for a chapel to be built in the nearby church of Santa Croce, if plans for enlarging the church were completed within ten years of his death (Borsook and Tintori 1965, 95, Appendix I, A). ${ }^{28}$ Donato was still alive in 1299, so he witnessed the beginning of the construction of new transept at Santa Croce in 1294. The friars gave the Peruzzi family a chapel in the south transept at an unknown 
date, but presumably before Giotto painted his celebrated frescoes there (figure 5; about 131116). Donato Peruzzi surely discussed his plans with the Franciscan friars before he drew up his will, and he clearly believed that it was possible to purchase a chapel in the church soon to be built. The friars probably intended to assign him one of the chapels on either side of the high altar, given that the chapels at the end of the transept were a later addition. Nevertheless, Peruzzi's plans to leave funds do not mean that he financed construction -- laborers had to be paid in cash daily. The transept was built primarily with public funds; only after the friars received the bequest did they cede one of the chapels to the Peruzzi.

The Franciscan friars may have always intended for one or more chapels in the transept to be sold to donors. This could even help explain why they built ten chapels in the transept, whereas the earlier church of Santa Maria Novella has only four (figures 1, 3). This hypothesis suggests that the government grants served as "seed money" that allowed the Franciscans to build their church, and thus obtain further funds from the private sector. Donato Peruzzi's will leaves open the possibility that at least some of the Santa Croce chapels were built on speculation. There is no doubt that the patronage rights for most of the transept chapels were sold after their construction. In 1334, Riccardo de' Bardi paid 200 florins (11 man-years) for his chapel in Santa Maria Novella. The price to obtain the rights to the high chapel was considerably higher. In his will of 1348, Albertaccio di Lapo degli Alberti left 2000 florins (67 man-years) for the endowment and decoration of the main chapel in Santa Croce, plus another 500 florins (17 man-years) for the materials and construction of his tomb.

Individual donations played an even more important role in the construction of the end chapels in the transepts of both churches. This type of chapel was defined by Marvin Trachtenberg as exceptional for its size, often double that of "standard" transept chapels; its 
location at the end of the transepts; and its elevation, atop a flight of stairs (Trachtenberg 1996; figures 1,3$)$. The construction history and unusual shape of these chapels indicate that they were built as additions to the transept, and were not part of the original plans for the churches. According to a new and convincing hypothesis by Giurescu, wealthy private individuals left substantial funds to build these new spaces only after the standard chapels were completed. Donors thus commissioned the exceptional chapels, supplied construction costs, and altered the shape of the churches. The chapel at the end of the north transept in Santa Croce, for example, was built only after Michele Castellani, in his will of 1383, left 1,000 florins (24.4 years) for the construction costs.

b. Santo Spirito. The sale of private chapels also played a principal role in supplying the construction costs for Santo Spirito (Luchinat and Capretti 1996; figures 6-7). In 1433, the Augustian friars decided to rebuild their church. The new church, designed by Brunelleschi, was built between 1477 and 1491. According to the analyses of Goldthwaite, the construction was "largely financed by the sale of its many chapels" (Goldthwaite 1980, 100). If the donations given for the thirty-nine chapels contributed three-quarters of the total cost (83,172 lire), the average price would be about 1,600 lire (10.7 man-years), or about 262.3 florins. Here we can be relatively certain that the chapel price far exceeded the cost of building it. Each chapel consists of two steps and a shallow niche framed in local limestone; the flanking columns outside the chapels can be considered part of the side aisle. The additional cost of each chapel, in comparison to building a straight wall, would hardly add up to even 50 florins, the cost of piercing the wall and adding a chapel to the church of Cestello, implying at least an 80 percent profit on selling cost. ${ }^{29}$ 
The prices of the chapels at Santo Spirito, and at most other churches, were set by members of the opera. In theory, the Church would want the opera to maximize income derived from the sale of chapels. Since all chapels are the exact same size and shape, it should charge the highest prices for those in the best spots, close to the high altar. In fact, the very opposite took place on several occasions (Burke 1999). Each member of the opera obtained a chapel, creating the potential for self-dealing. At least some paid highly discounted rates, e.g., only 50 to 100 florins (2.2 - 4.4 man-years) for chapels in the transept; other donors, who were not members of the opera, had to pay higher fees, e.g., 150 florins, for less prestigious chapels in the nave. In the $1480 \mathrm{~s}$ and $1490 \mathrm{~s}$, the price for at least six transept chapels was 300 florins (17.3 man-years). ${ }^{30}$ But one of the most desirable chapels, behind the high altar, was given at no cost to Luca Pitti, a member of the opera. The friars intervened directly in the decision-making process in order to reward the local banker, of whom they said, "with his wisdom he has increased the income of the said opera." Pitti evidently received a chapel after he had made a large donation to the building committee. As with many nonprofits today, major donors were given valuable gifts in recognition of previous donations, and in hope of future ones. This important example shows that even with extensive documentation, recorded evidence about what churches received for chapels is likely to understate their long-term receipts.

2. Tie-In Arrangements with the Sale of Chapels. Donors were expected to outfit and adorn their chapels at their own expense. Though the church did not profit directly from these activities, it received honorably decorated spaces at no cost. Donors also purchased additional services from the church, sometimes at a later date. The most important such services were paid private masses, and funerals and burials. 
a. Outfitting chapels. Each chapel needed an altar table and crucifix, as well as the objects used during the mass, including missals, candlesticks, chalices, bells, ewers, cloths, censers, and priestly vestments (Gardner 1994). In prestigious chapels these objects were made of precious metals, and were often more expensive than the paintings and sculptures. For his chapel in Santa Maria Novella, for example, Filippo Strozzi spent 135 florins (6.1 man-years) between 1488-90 on priestly vestments alone. For the altar table, tomb, and marble relief sculpture of the Madonna and Child, Filippo and his heirs paid 437 florins (25 man-years) to the sculptor Benedetto da Maiano.

b. Decorations. Many chapels had altarpieces (usually painted), elaborate frames, frescoes, or stained glass windows, and more prominent chapels often had several of these decorations (figures 2, 5, 7). These objects, together with the tombs in chapels, comprise the vast majority of the Renaissance church art that we admire today. These decorations were not required for the celebration of the mass, though altarpieces did fulfill the obligation that an image or inscription must identify the person, object, or mystery to which the altar was dedicated. During our period, the average cost for an altarpiece by a respected artist was about 100 florins, but some works naturally cost much more. For the fresco decorations in the Strozzi chapel, Filippino was paid 350 florins (19.3 man-years). Cohn's analysis of wills made by Tuscans of widely different social classes, from humble shopkeepers to wealthy bankers, showed that the average sum left for sacred art was about 27 florins, about 10 percent of the average sum left for obtaining a chapel (Cohn 1992, 245).

c. Paid Private Masses. Like many nonprofits in the modern era, the Renaissance church offered services for a fee: paid private masses. Donors invariably left funds for masses to be held in their chapels; for the churches, these represented a form of tie-in sale. These masses usually consisted 
of post mortem commemorations, and masses in honor of the patron saint(s) of the chapel and of the donor. These commemorations often included a meal, which could range from a simple repast for the celebrant to banquets for a large number of priests, friars, and other invited guests. The study of one community of friars shows that during eight months of 1528 , the friars ate commemorative meals on more than one day in three (36.6 percent of days). This type of privately sponsored remembrance led to Luther's charge that the clergy "ate" off the dead (Strocchia 1992). Payments for masses provided much of the income for most priests, and one modern scholar even observed that late medieval churches had become "veritable mass factories" (Oakley 1979, 118).

For a set fee, donors could pay for a number of masses to be said soon after a funeral. Among the most popular funeral formulas was the Gregorian mass series, which consisted of one mass daily for thirty days after death. In 1490, this option cost about 1 florin (14.3 man-days). Wealthy donors, however, often requested many more masses: in 1411, the testament by the widow of Andrea Cavalcanti left provisions for one thousand masses, to be held within the first two months after her death, in a chapel in Santa Maria Novella. Across Florence, churches performed thousands of funerary masses each year.

Donors could also set up anniversary masses; these were usually officiated on the date of the donor's death, and on the feast day of the saint to whom the chapel was dedicated. To guarantee these complex and continuing services, testators placed restrictions on their gifts, often including inspection by heirs, with the threat of substituting alternative charities if wishes were not met. ${ }^{31}$ In the 1400 s, the average bequest for masses was 15 florins per year. Usually donors gave or shared the ownership of a farm or shop with the church; these properties were rented out to third parties, which provided income to pay for the masses. A new development in late 1400s 
was short-term anniversary masses, to be performed 5, 10, or 25 years after death. These less frequent and cheaper services allowed shopkeepers and small tradesman to provide for their own spiritual well-being and remembrance. At the other end of the economic scale, some very wealthy donors created "chaplaincies," endowed positions designed to guarantee the singing of mass for the souls of specified persons (Colvin 1991, 152-89). ${ }^{32}$ A substantial endowment was required to support these chaplains; in 1433, for example, Luca di Marco left 1,000 florins (35 man-years) for the construction of his chapel in the church of San Lorenzo and the support of an associated chaplaincy. To ensure that masses were carried out, donors often left only a small sum as a base salary ("prebend") for the chaplain, and a much higher amount for the performance of liturgical duties. By offering a range of options, from short-term anniversary masses to chaplaincies, price discrimination was introduced into the sale of remembrances. ${ }^{33}$ d. Burials and funerals. Funerals and burials brought considerable sums to local churches. Wealthy patrons regularly spent far more on funerals than on the altarpieces and frescoes that so captivate modern visitors to churches and museums. In the 1400 s, the cost of prominent funerals ranged from 300 to 700 florins ( 8.1 - 19.6 years), excluding the price of tombs or commemorative masses, but a few exceptional funerals cost far more -- up to one hundred manyears. ${ }^{34}$

Most of this money was spent on candle wax, funeral clothes, and processions; payment for them did not go to the local churches. The friars and priests were paid directly to participate in the funerary procession, and they also received the appropriate clothes; this fabric could be reused or sold. At major funerals, the large wax candles were often lit for only a brief period, then donated to the church where the event took place. This constituted a significant tie-in benefit for the church, given the remarkable amount of expensive wax purchased for funerals. 
The standard amounts were 10-20 pounds for artisans, and 50-60 pounds for physicians and notaries, but wealthy citizens might purchase ten times this amount. At the small church of San Pier Maggiore, burial revenues from cloth, wax, and clerical fees account for 22 percent of the total income in the plague year of 1374 , and a respectable 10 percent in a sampling of years with more normal mortality rates between 1374 and 1413 (Strocchia 1992, 91).

3. Private Chapels and Employment. If the Renaissance churches became mass and funeral "factories," they needed increasing numbers of workers to maintain their production. Many churches brought in outside priests on a contract basis to perform post mortem commemorations. This practice became so widespread that an official decree in 1517 condemned clergy who neglected duties at their own churches in order to celebrate masses at other institutions for pay. Over time, however, the demand for privately sponsored masses and prayers called for an everexpanding number of priests and friars, allowing the religious orders to dramatically increase their numbers. This in turn led to the need for new or enlarged living quarters, and the construction of these convents and monasteries was often supported by private donations. The dramatic growth in the size of the religious orders, and in the number of priests and religious, created many new opportunities for promotion -- new churches needed priors, and religious orders needed to fill their hierarchies.

\section{The Demand Side: Benefits to Donors from the Purchase of Chapels}

The incentives for churches to sell private chapels are clear. They needed vast funds for the construction, embellishment, and staffing of ecclesiastical structures, and they reaped a handsome profit and a continuing source of revenue from tie-in sales. But why should donors pay significantly above cost, or even just pay significantly, to purchase chapels that were so 
rarely used by them and their families? Good will and altruism would not be sufficient motivation, but the purchase of private chapels offered many benefits not available anywhere else. We analyze the two primary benefits: the hope of a speedy passage through Purgatory would help the donors in the afterlife; and the status one reaped from being known as a generous donor to the church provided both immediate benefits and posthumous fame. ${ }^{35}$

1. Afterlife. Funerary masses and burial within private chapels offered the possibility of alleviating the pains of Purgatory, a service that could not be purchased outside the Church. Donors rarely discussed this point in the surviving statements about chapels. Filippo Strozzi, for example, wrote about why he contributed funds to the renovation of three churches: "God having conceded temporal goods to me, I want to be grateful to Him for them" (Sale 1976, 18). ${ }^{36}$ But the owners of individual chapels, familiar with theory of indulgences, must have considered their purchase and embellishment of these spaces to be good deeds that would count in their favor when they died. More directly, they paid for private masses in the expectation that these would advance the exit from Purgatory.

Tombs located in chapels could also help donors in the afterlife. Saint Antoninus spelled out three advantages of burials within churches: the saints honored by the church would intercede on behalf of the deceased; the faithful, coming to church, would see the tomb and pray for the deceased; and the dead would be assured of rest undisturbed by demons (Gaston 1987, 131). Starting in the mid-1200s, a series of papal bulls gave Franciscan and Dominican friars permission to bury the faithful inside their churches, an honor previously reserved for the religious. The powerful desire for intramural burials led patrons to buy burial plots in the pavement of churches, and in the crypts below. ${ }^{37}$ 
For Renaissance Florentines who did not have a personal or family chapel, a prime motivation for acquiring one was to have burial ground -- but the wish to be buried in a church does not sufficiently explain the proliferation of memorial chapels. Most families who had chapels in the transepts of Santa Maria Novella, Santa Croce, and Santo Spirito had at least one other chapel in a different church, and only one of these spaces was used for burial. Moreover, an omnipotent God would know who the donors were; a specific chapel associated with one's name was not needed.

2. Status. Girolamo Savonarola, the prior of San Marco in the 1490s, and (in)famous today for his bonfire of the vanities, understood that status was a major benefit of owning a chapel. The Dominican friar complained that he could not convince wealthy men in Florence to give 10 florins to the poor, but they would give 100 florins just to put their coat of arms on a chapel. He accused the merchants: you do this "for your honor, not for the honor of God." Statements by donors themselves support Savonarola's view. When Giovanni Tornabuoni drew up a contract for the fresco decoration of the high chapel in Santa Maria Novella (figure 2), he presented this commission as "exaltation of his house and family," as well as "an act of piety and love of God...and [for] the enhancement of the said church and chapel." High status within one's local community was often identified by Renaissance authors as a goal in and of itself. It also brought other benefits. One could make advantageous marriage agreements for one's self or children. Status fostered the acquisition or retention of power in a period of constantly shifting political alliances; the Medici, for example, were banished from Florence three times over the period studied. Power in turn brought wealth. 
Status was predominantly a function of wealth and social ties that often could not be demonstrated directly, particularly since religious leaders advocated humility and selfeffacement. Sumptuary laws and local traditions also significantly limited displays of conspicuous consumption. Thus, substantial expenditures on publicly displayed prestigious works were often the best way to signal one's status and wealth. Many Renaissance texts present the construction of buildings, especially religious ones, as a virtuous activity, exemplifying the donor's "magnificence." When one paid for a specific commission like a chapel, one's identity could be prominently displayed. Patrons tried to distinguish themselves through the placement, type, and decoration of their chapels.

Private chapels succeeded in signaling status for two main reasons: they were exclusive and highly visible. In major Tuscan churches, the price of a chapel was beyond the means of all but the wealthy. According to Cohn $(1992,214)$, the average sum left for a chapel between 1276 to 1425 was 208.9 florins, excluding costs of masses and decorations; this is more than the total assets of most testators. ${ }^{38}$ The even higher cost of decorating, outfitting, and staffing chapels strengthened the signal. Thus, if the chapel was finely decorated with luxurious materials or with works by respected artists, it further enhanced the donor's status. In effect, viewers could calibrate the donor's status by considering the size and intricacy of works, the cost of the materials, the distinction of the artists, and the location within the church.

Though entry into many chapels was blocked by gates, men in the church could easily gaze above and through the barriers at the decorated spaces. Private chapels displayed large and colorful indications of ownership: names, coats of arms, emblems, and banners. Savonarola himself fumed that donors had their symbols placed "on the 
back of vestments, so that when the priest stands at the altar, the arms can be seen well by all the people." In the early fourteenth century, one donor even obliged the friars at Santa Maria Novella and Santa Croce to proclaim each year, before the congregation, how generous he had been (Cohn 1992, 104-107). The Renaissance patrons who used their chapels and decorations to signal and advance their status would have little to learn from modern-day philanthropists.

\section{Conclusion}

Many nonprofit organizations have shown themselves to be remarkably durable. Long life for such organizations requires solid financing. Yet such organizations are in the public benefits business, which raises the free-rider dilemma. Many of the most successful modern nonprofits offer donors private benefits, often status and a form of immortality, in exchange for contributions. This mechanism helped drive Harvard University's recent $\$ 2.6$ billion capital fund drive. The University received 490 gifts of $\$ 1$ million or more. Natural modesty, security concerns, and a desire to avoid solicitations by other nonprofits might motivate many donors to make their gifts anonymously. Those whose goal was merely to "give back to the University" might provide money to general funds, such as the scholarship pool; as opposed to a named specified purpose, such as a professorship or building wing, which gives lasting recognition. But

$94.5 \%$ of donors chose to be identified, and $84.2 \%$ of these gifts were made to named purposes. ${ }^{39}$ Presumably Harvard's contemporary donors shared some of the status and immortality goals as donors to churches in Renaissance Florence. They were securing a permanent link to a prestigious and long-lived institution. 
Starting in the late Medieval period, Florence's churches found an essential new instrument to to raise money, which allowed them to build and thrive: the sale of private chapels. This "commodity" was highly valued, could not be produced by others, and brought in considerable related benefits to the church. Since status was a donor goal, more prestigious churches could charge far higher prices. Beyond status, donors received burial locations, a form of immortality and, with the purchase of accompanying masses, the hope for a shorter stay in Purgatory. The citizenry had their city beautified, their God glorified, and magnificent churches where they could worship. Thus the major nonprofits of Renaissance Florence, its churches, supported themselves by effecting a market transaction that exchanged private benefits for public goods. 


\section{List of Illustrations}

1. Florence, Church of Santa Maria Novella, plan of interior, drawing, 18th Century. Note: entrance on far right; main chapel on far left (A); high altar (B); private chapels in aisles along the nave (C) and in transept arms on either side of main chapel (C); "exceptional" chapels $(I, G)$; sacristy (D).

2. Florence, Church of Santa Maria Novella, nave and side aisles.

Note: view is toward high altar and main (Tornabuoni) chapel, with frescoes by Domenico Ghirlandaio, late 15th century. Chapels visibile in side aisles, including the Lenzi Chapel on the left, with Masaccio's Trinity, early 15th century.

3. Florence, Church of Santa Croce, plan of interior, drawing, 18th Century. Note: entrance on far right (R); main chapel on far left (L); high altar (I); private chapels in aisles along the nave, and in transept arms on either side of main chapel (A); "exceptional" chapels (N, E); sacristy $(\mathrm{G})$.

4. Florence, Church of Santa Croce, view of interior, engraving, 19th Century.

Note: view is toward toward high altar and main (Alberti) chapel; chapels visible in side aisles.

5. Florence, Church of Santa Croce, view of two chapels to right of high altar.

Note: Bardi Chapel (left), Peruzzi Chapel (right), both with frescoes by Giotto, early 14th century.

6. Florence, Church of Santo Spirito, plan of interior, drawing, 18th Century.

Note: entrance on far left (D); main chapel on at right (C); high altar (A); private chapels in aisles along the nave and transept $(\mathrm{B})$; sacristy $(\mathrm{F})$.

7. Florence, Church of Santo Spirito, view of three chapels in transept.

Note: the chapel on the far right is indicated with a "O" in figure 6, on the "Orto del Frescobaldi" side. All chapels have original architectural elements designed by Brunelleschi, early 15th century, and original altar tables, altarpieces, frames, and altar frontals from late 15th - early 16th centuries.

8. Florence, Church of Cestello (now Santa Maria Maddalena de' Pazzi), plan of interior, drawing, 18th Century.

Note: street entrance on far left (A); courtyard (D); church entrance (E), nave (F); main chapel on at right $(\mathrm{G})$; private chapels along nave $(\mathrm{H})$; sacristy $(\mathrm{L})$.

Source: Florence, Kunsthistorisches Institut. 


\section{Bibliography}

Bizzocchi, Roberto. Chiesa e potere nella Toscana del Quattrocento. Bologna: Il Mulino, 1987.

Blume, Andrew C. “Giovanni de' Bardi and Sandro Botticelli in Santo Spirito.” Jahrbuch der Berliner Museen 73 (1995): 169-183.

Borsook, Eve, and Leonetto Tintori. Giotto: The Peruzzi Chapel. Turin: Fratelli Pozzo, 1965.

Burke, Jill. "Form and Power: Patronage and the Visual Arts in Florence c. 1478 - 1512," Ph.D. dissertation, Courtauld Institute, University of London, London, 1999.

Ciappelli, Giovanni, and Patricia Rubin, eds. Art, Memory, and Family in Renaissance Florence. Cambridge: Cambridge University Press, 2000.

Cipolla, Carlo M. Il governo della moneta a Firenze e a Milano nei secoli XIV-XVI. Bologna: Mulino, 1990.

Cohn, Samuel K., Jr. Death and Property in Siena, 1205-1800: Strategies for the Afterlife. Baltimore: Johns Hopkins University Press, 1988.

Cohn, Samuel K., Jr. The Cult of Remembrance and the Black Death. Six Renaissance Cities in Central Italy. Baltimore and London: Johns Hopkins University Press, 1992.

Colvin, Howard. Architecture and the After-life. New Haven and London: Yale University Press, 1991.

de Tocqueville, Alexis. Democracy in America [1835]. New York and Baltimore: Knopf, 1976.

Eckstein, Nicholas A. The District of the Green Dragon: Neighborhood Life and Social Change in Renaissance Florence. Florence: Olschki, 1995.

Elam, Caroline. “Cosimo de' Medici and San Lorenzo.” In Cosimo 'il Vecchio' de' Medici: Essays in Commemoration of the 600th Anniversary of Cosimo de' Medici's Birth, ed. Francis Ames-Lewis, 157-180. Oxford: Claredon Press, 1992.

Gardner, Julian. "Altars, Altarpieces, and Art History: Legislation and Usage.” In Italian Altarpieces: Function and Design 1250-1550, eds. Eve Borsook and Fiorella Superbi Giofredi, 5-40. Oxford: Claredon Press, 1994.

Gaston, Robert. "Liturgy and Patronage in San Lorenzo, Florence, 1350-1650." In Patronage, Art, and Society in Renaissance Italy, eds. F.W. Kent and Patricia Simons, 111-134. Oxford: Claredon Press, 1987.

Giurescu, Ena. "Family Chapels in Santa Maria Novella and Santa Croce: Architecture, Patronage, and Competition.” Ph.D dissertation, New York University, 1997. 
Goldthwaite, Richard A. Private Wealth in Renaissance Florence. Princeton: Princeton University Press, 1968.

Goldthwaite, Richard A. The Building of Renaissance Florence: An Economic and Social History. Baltimore and London: Johns Hopkins University Press, 1980.

Goldthwaite, Richard A. Wealth and the Demand for Art in Italy 1300-1600. Baltimore and London: Johns Hopkins University Press, 1993.

Goldthwaite, Richard A., and Giulio Mandich. Studi sulla moneta fiorentina (secoli XIII-XVI). Florence: Olschki, 1994.

Haines, Margaret, and Lucio Riccetti, eds. Opera: carattere e ruolo delle fabbriche cittadine fino all 'inizio dell'Età Moderna. Florence: Olschki, 1996.

Hall, Marcia B. Renovation and Counter-Reformation. Vasari and Duke Cosimo in Sta. Maria Novella and Sta. Croce 1565-1577. Oxford: Claredon Press, 1979.

Hansmann, Henry. “The Role of Nonprofit Enterprise.” Yale Law Journal 539 (1990): 835-901.

Höger, Annegret. "Studien zur Entstehung der Familienkapelle und zu Familienkapellen und Altaren des Trecento in Florentiner Kirchen.” Ph.D. dissertation, University of Bonn, 1976.

Kent, Dale. Cosimo de' Medici and the Florentine Renaissance: The Patron's Oeuvre. New Haven and London: Yale University Press, 2000.

Kent, F.W. "Individuals and Families as Patrons of Culture in Quattrocento Florence." In Language and Images in Renaissance Italy, ed. Alison Brown, 111-134. Oxford: Claredon Press, 1995.

Luchinat, Cristina Acidini, and Elena Capretti, eds. La chiesa e il convento di Santo Spirito a Firenze. Florence: Giunti, 1996.

Luchs, Alison. Cestello. A Cictercian Church of the Florentine Renaissance. (Ph.D. dissertation, Johns Hopkins University, 1975), New York and London: Garland, 1977.

Molho, Anthony. Marriage Alliance in Late Medieval Florence. Cambridge: Harvard University Press, 1994.

Nelson, Jonathan Katz. "Memorial Chapels in Churches: The Privatization and Transformation of Sacred Spaces." In Florence. Re-Visioning the Renaissance City: Art, Patronage, and the Dynamics of Space, eds. Roger J. Crum and John T. Paoletti. Cambridge: Cambridge University Press, forthcoming. 
Nova, Alessandro. "Hangings, Curtains and Shutters of Sixteenth-Century Lombard Altarpiece." In Italian Altarpieces. Function and Design 1250-1550, eds. Eve Borsook and Fiorella Superbi Giofredi, 177-189. Oxford: Claredon Press, 1994.

Oakley, Francis. The Western Church in the Later Middle Ages. Ithaca, NY: Cornell University Press, 1979.

Olson, Mancur. The Logic of Collective Action: Public Goods and the Theory of Groups. Cambridge: Harvard University Press, 1965.

Saalman, Howard. Brunelleschi. The Buildings. London: Zwemmer, 1993.

Salamon, Lester M. America's Nonprofit Sector: A Primer. New York: Foundation Center, 1999.

Sale, J.R. The Strozzi Chapel by Filippino Lippi in Santa Maria Novella. (Ph.D. dissertation, University of Pennsylvania, 1976). Ann Arbor and London: Garland, 1976.

Spence, A. Michael. Market Signaling: Informational Transfer in Hiring and Related Screening Processes. Cambridge: Harvard University Press, 1974.

Strocchia, Sharon T. Death and Ritual in Renaissance Florence. Baltimore and London: Johns Hopkins University Press, 1992.

Swanson, R.N. Religion and Devotion in Europe, c. 1215 - c. 1515. Cambridge: Cambridge University Press, 1995.

Trachtenberg, Marvin. “On Brunelleschi's Old Sacristy as Model for Early Church Architecture." In L'Église dans l'Architecture de la Renaissance, ed. Jean Guillaume, 9-40. Paris: Picard, 1996.

Weisbrod, Burton. The Voluntary Nonprofit Sector: An Economic Analysis. Lexington, MA: Lexington Books, 1977.

Zeckhauser, Richard J., and David V.P. Marks. "Sign Posting: The Selective Revelation of Product Information." In Wise Choices: Decisions, Games, and Negotiations, eds. Richard J. Zeckhauser, Ralph L. Kenney, and James K. Sebenius, 22-41. Boston: Harvard Business School Press, 1996. 


\section{Endnotes}

${ }^{1}$ The authors thank the participants in the Januay 2002 NBER Conference on Not-for-Profit Organizations and the February 2002 College Art Association Annual Conference session on Conspicuous Commissions: Status Signaling Through Art in the Italian Renaissance, and Edward Glaeser and Bruce Weinberg in particular, for helpful comments. We also thank Marta Alvarez Gonzalez for excellent research assistance.

${ }^{2}$ De Tocqueville (1835), especially pp. 191-98, on political associations.

${ }^{3}$ Weisbrod (1997) shows how nonprofit organizations overcome market failures in the provision of public goods to particular groups.

${ }^{4}$ For the "non-distribution constraint" as a criterion for a nonprofits, see Hansmann 1990.

${ }^{5}$ For an action to be an effective signal, the prestigious group must find it less costly to take than would others. For example, a college degree is less costly for smarter people to secure, and a costly chapel is more likely to be purchased by someone who is rich. See Spence 1974, especially pp. 62-68 (chapter 8, "Status, Income, and Consumption"); and Zeckhauser and Marks 1996.

${ }^{6}$ The new Catholic Cathedral in Los Angeles is offering prestigious final resting spots for sale (1,300 crypts and 5,000 niches for ashes), with crypts starting at \$50,000. See "Cathedral in Los Angeles Sets Premium on Its Crypts," New York Times, February 10, 2002, p. 20.

${ }^{7}$ The price of buildings, chapels, and their artistic decorations were usually calculated in florins, an internationally recognized gold-based coin, but wages and living expenses were usually given in lire. Between 1350 and 1500, the value of the lire to the florin fell in half from 3.5:1 to 7:1 (Goldthwaite and Mandich 1994; Cipolla 1990). Different currencies were used for different types of items. Similarly, some countries today employ dollars for major transactions, but the local currency for day-to-day purchases.

${ }^{8}$ Man-year figures are always approximate, and we round off those above 20. Goldthwaite's (1980) data allow one to determine the lire/florin exchange rate and the rate of pay for any given year, and therefore enable us to hone the calculation of the cost of a man-year.

${ }^{9}$ On burials and strategies for preserving the memory of Florentines, also see Ciappelli and Rubin 2000 .

${ }^{10}$ For general essays, see Colvin 1991, pp. 190-217 (chapter 10, “The Family Chapel in Renaissance Italy"); and Nelson forthcoming.

${ }^{11}$ For Renaissance Tuscany, see Bizzocchi 1987; for more general discussions, see Swanson 1995.

${ }^{12}$ On rood screens and choirs in Florence, see Hall 1979. 
${ }^{13}$ By way of contrast, most private chapels in Venice were owned by brotherhoods or scuole. Though the purchasers of chapels received private property in return, they were regularly described in Renaissance Italy as benefactors, and we refer to them as donors.

${ }^{14}$ For North Italy, see Nova 1994, pp. 177-89.

${ }^{15}$ Some modern nonprofits that have constructed named buildings upon merely receiving their construction costs -- or worse, just a fraction of them -- have encountered financial difficulties. Many nonprofits now push hard to get some assurance of support for maintenance, recognizing that they may have to settle for fewer and less grand buildings.

${ }^{16}$ The Catasto was a financial statement that included assessments of real estate and liquid wealth; this provided the basis for the government to levy forced loans. For practical purposes, such loans can be compared with taxes. See Goldthwaite 1968.

${ }^{17}$ For the declared worth of many prominent Florentines, see Molho 1994. For Cosimo de' Medici, see Kent 2000; for Niccolò Alberti, see Strocchia 1992, p. 77; for Filippo Strozzi, see Goldthwaite 1968, pp. 60, 63.

${ }^{18}$ Construction of the cloister, or living quarter for the friars, was included in the figure for San Pancrazio but not for Santo Spirito.

${ }^{19}$ This approach is much in the spirit of the contemporary university, which sells a building to one person, then rooms within it to others. Often such rooms are not sold until years after the building is completed.

${ }^{20}$ No explanation is given for the considerable differences in construction costs, which ranged from 50 to 70 florins.

${ }^{21}$ Many modern nonprofits also have construction activities lasting more than a century, though rarely for a single building.

${ }^{22} \mathrm{~A}$ modern analogy might be a state university system or a large private university; most appointments and financial decisions are made by the local colleges and universities, and are generally approved by the chancellor.

${ }^{23}$ On this institution, see Haines and Riccetti 1996; and Goldthwaite 1980, pp. 90-94.

${ }^{24}$ As discussed below, the construction funds for Santo Spirito were raised from the sale of private chapels, but starting in 1445, the friars there and at Santa Maria del Carmine did receive proceeds from a salt tax to help offset expenses.

${ }^{25}$ All information relating to the early history of these churches derives from Giurescu 1997. 
${ }^{26}$ For example, what edge, if any, should the children of large donors have in getting into prestigious colleges?

${ }^{27}$ Thus, support of a church might be thought of as a "directed good." Though providing benefits to a general public, a directed good provides dramatically disproportionate benefits to a small segment of the population. In the contemporary context, the provision of education is often identified as a public good, since it produces a better citizenry. But citizen $\mathrm{X}$ is the overwhelming beneficiary from his or her education, so that education is a directed good.

${ }^{28}$ The original Latin document refers to "libras," which most authors render as libbre (pounds), but in this context presumably indicates the lire coin.

${ }^{29}$ This comparison understates Santo Spirito's profits, because it was planned to include side chapels, but these were added to Cestello.

${ }^{30}$ Blume 1995, p. 172, note 33, records the price of 300 florins for the Biliotti, Ridolfi, Lanfredini, and Dei chapels. In 1493 the Nerli chapel cost 300 florins, and in 1495 the Segni chapel cost the unusually high price of 500 florins (31 man-years). See Luchs 1977, p. 159, note 5. The Luti chapel cost 300 florins, see Burke 1999.

${ }^{31}$ Donors to modern universities have equivalent concerns about fidelity to their wishes, and sometimes stretch contributions over time to establish precedents and make fidelity more likely.

${ }^{32}$ For San Lorenzo, see Gaston 1987, pp. 112-113. For prices for chaplaincies, often combined with those for transept chapels, see Elam 1992, pp. 157-180.

${ }^{33}$ In the world of academia, these arrangements might be compared to a conference, an annual lecture, and an endowed professorship.

${ }^{34}$ The following examples are discussed in Strocchia 1992: 1353 (Acciaiuoli), 5,000 florins; 1377 (Alberti) 3,000 florins or 94.8 years; 1429 (Medici), 3,000 florins or 93.1 years; 1432 (Tornabuoni), 1056 florins or 36.4 years; 1491 (Strozzi) 1,222 florins or 64.7 years, for ceremonies in Florence and Naples.

${ }^{35}$ Surviving evidence rarely allows us to determine the relative importance of these two benefits for any given donor, though the type of decoration may indicate the weight given to salvation or status.

${ }^{36}$ In the same letter of 1477, Filippo wrote, "God having granted us His grace, there is no harm in our recognizing it in some way."

${ }^{37}$ According to Cohn's $(1992,143)$ analysis of Tuscan testaments, only 20 percent of wills made in the period before 1363 indicate a specific burial location, but in the early 1400s, two-thirds are specific. 
${ }^{38}$ This figure covers the period 1276 to 1425 , during which the florin changed value dramatically, and so it cannot be converted into a single man-year equivalent. These figures apply to several cities and the surrounding countryside, so the prices of a chapel in Florence was certainly far higher.

${ }^{39}$ Personal conversations with Sarah Clark and Thomas Reardon, Harvard University Development Office, March 19, 2002. 
Piazia Vecthia.

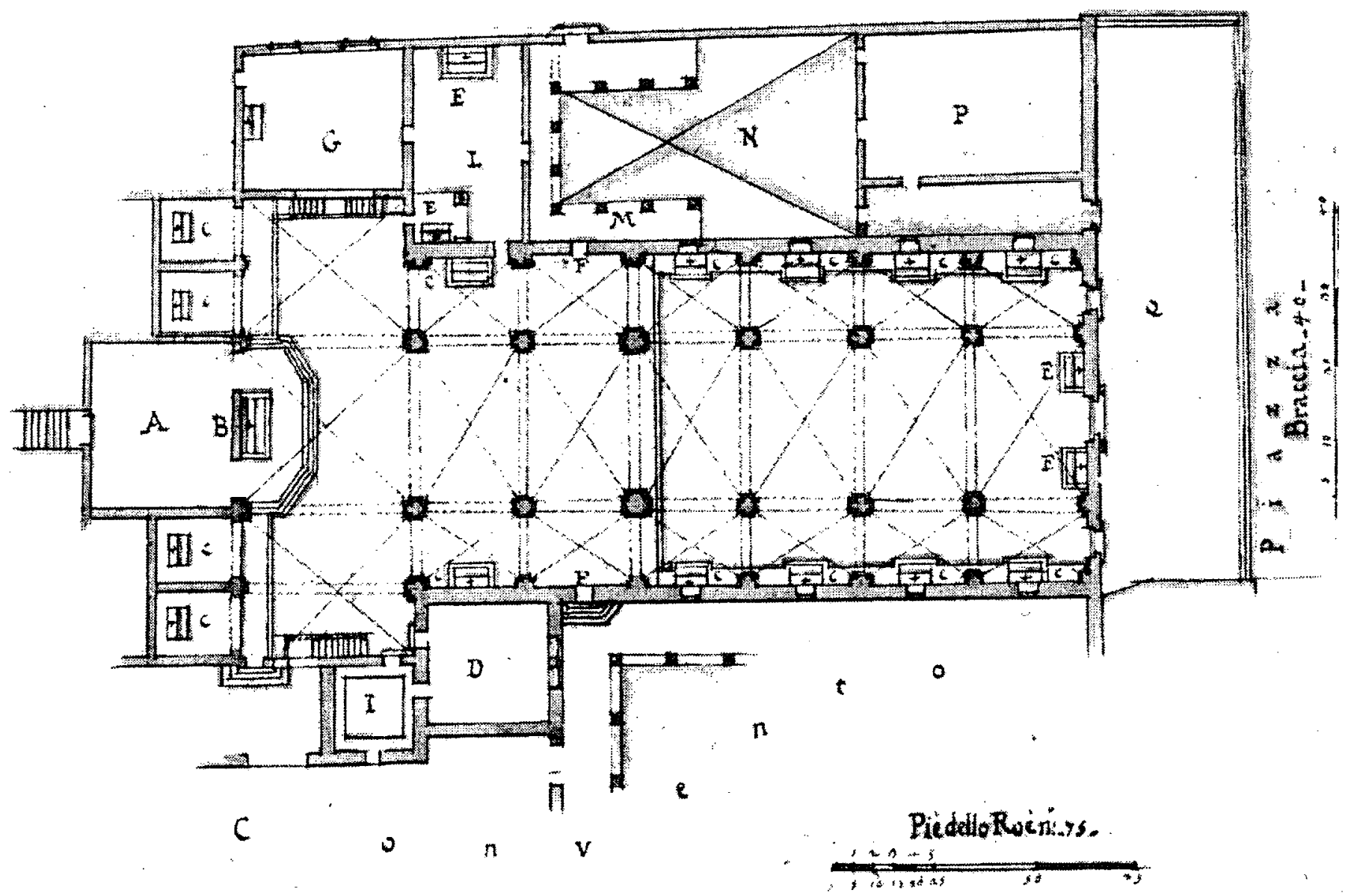

1. Florence, Church of Santa Maria Novella, plan of interior, drawing, 18th Century.

Note: entrance on far right; main chapel on far left (A); high altar (B); private chapels in aisles along the nave (C) and in transept arms on either side of main chapel (C); "exceptional" chapels (I, G) ; sacristy (D). 


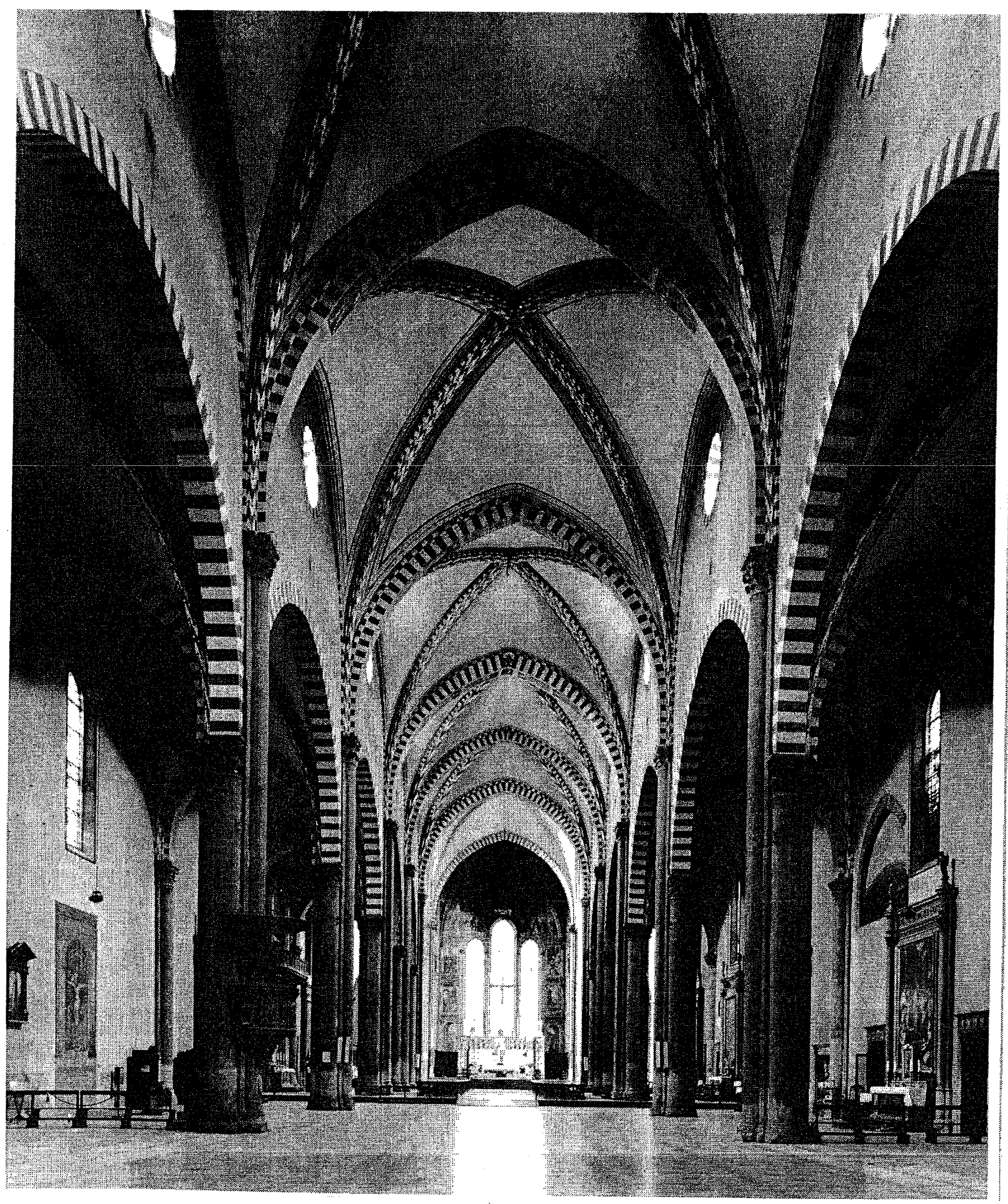

2. Florence, Church of Santa Maria Novella, nave and side aisles. Note: view is toward high altar and main (Tornabuoni) chapel, with frescoes by Domenico Ghirlandaio, late 15th century. early 15 th century. 


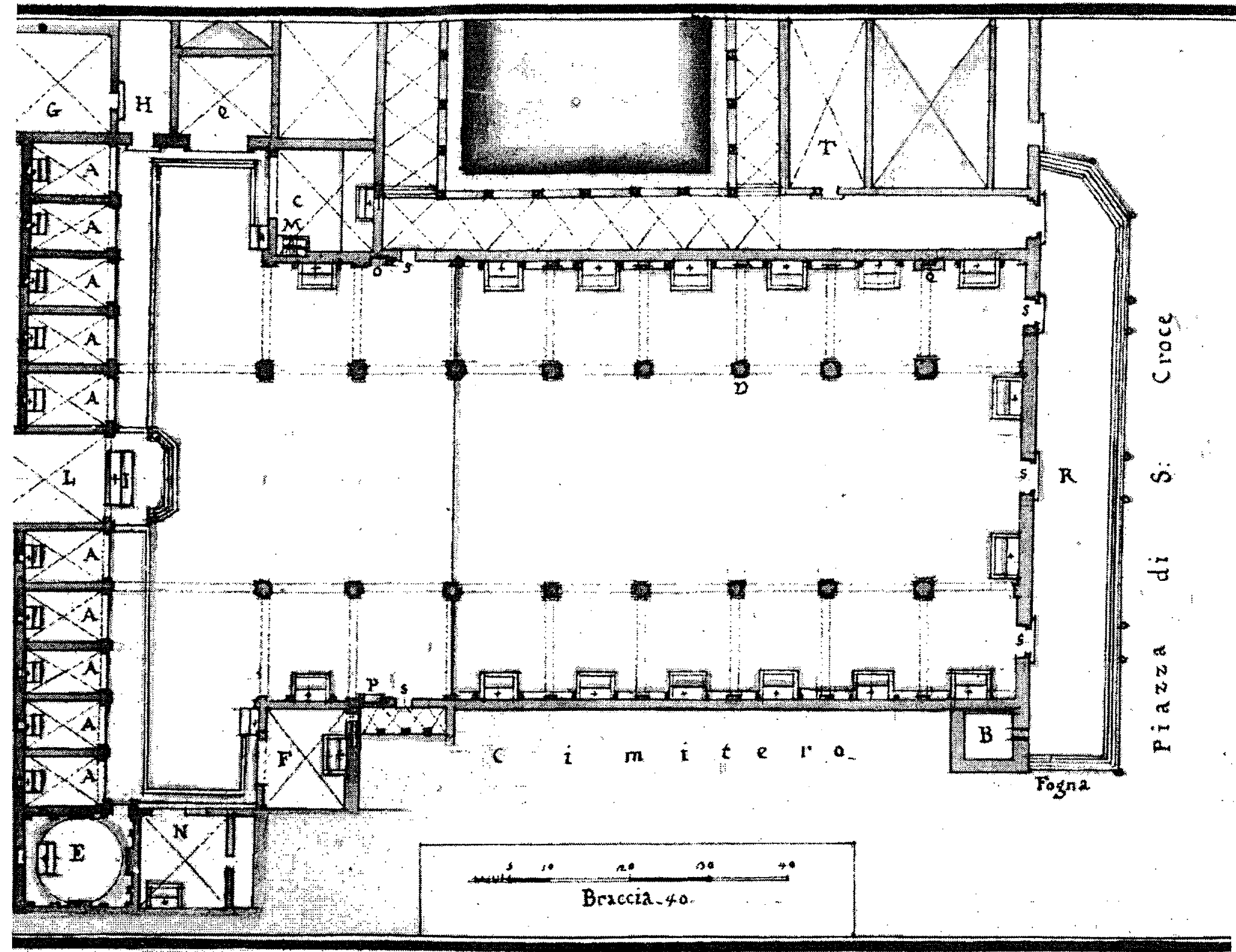

3. Florence, Church of Santa Croce, plan of interior, drawing, 18th Century. Note: entrance on far right (R); main chapel on far left (L); high altar (I); private chapels in aisles along the nave, and in transept arms on either side of main chapel (A); "exceptional" chapels (N, E); sacristy (G).

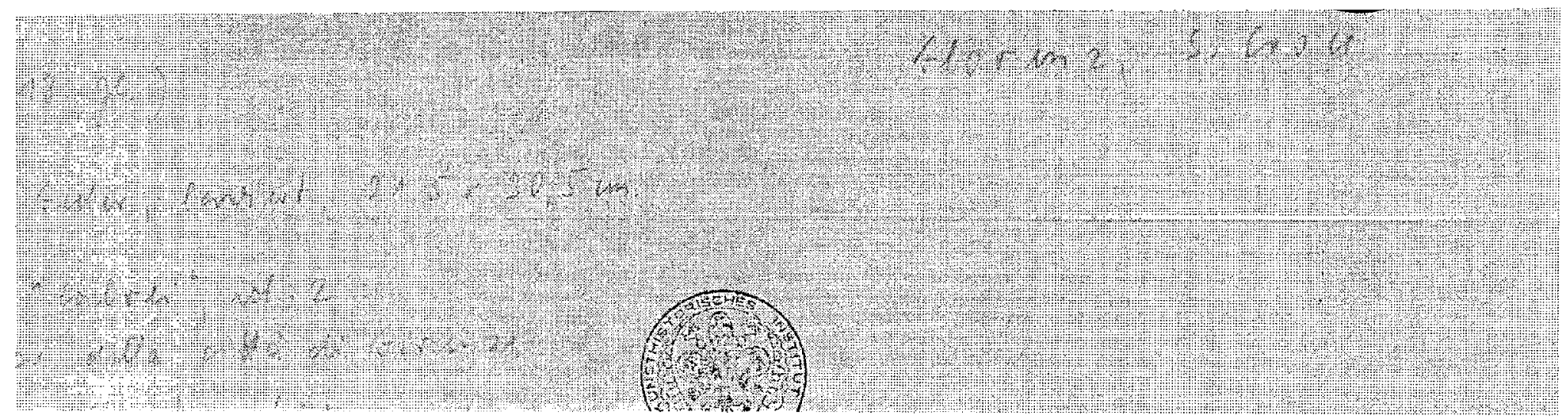


$159 a$


4. Florence, Church of Santa Croce, view of interior, engraving, 19th Century.

Note: view is toward toward high altar and main (Alberti) chapel; chapels visible in side aisles. 
5. Florence, Church of Santa Croce, view of two chapels to right of high altar.

Note: Bardi Chapel (left), Peruzzi Chapel (right), both with frescoes by Giotto, early 14th century.

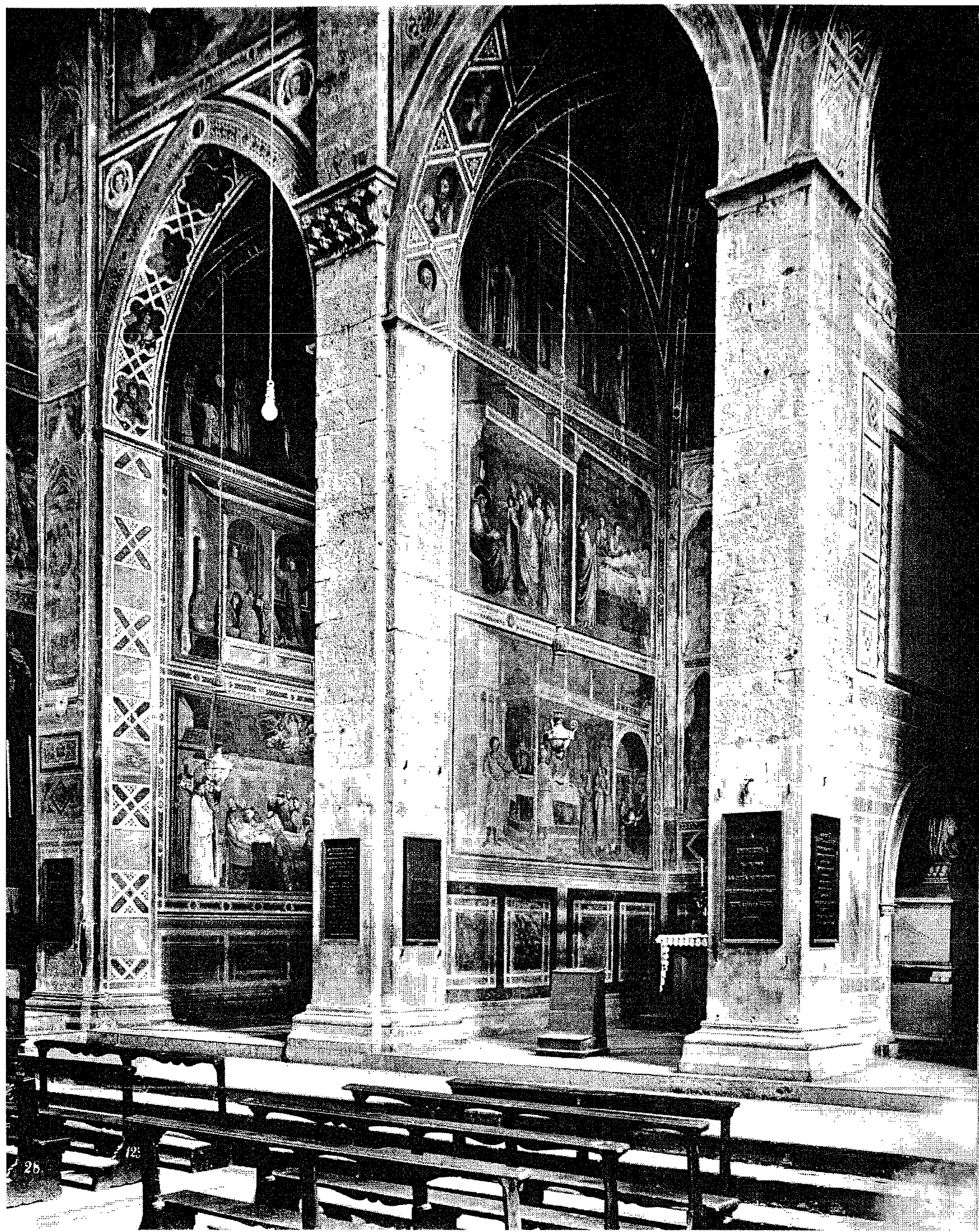




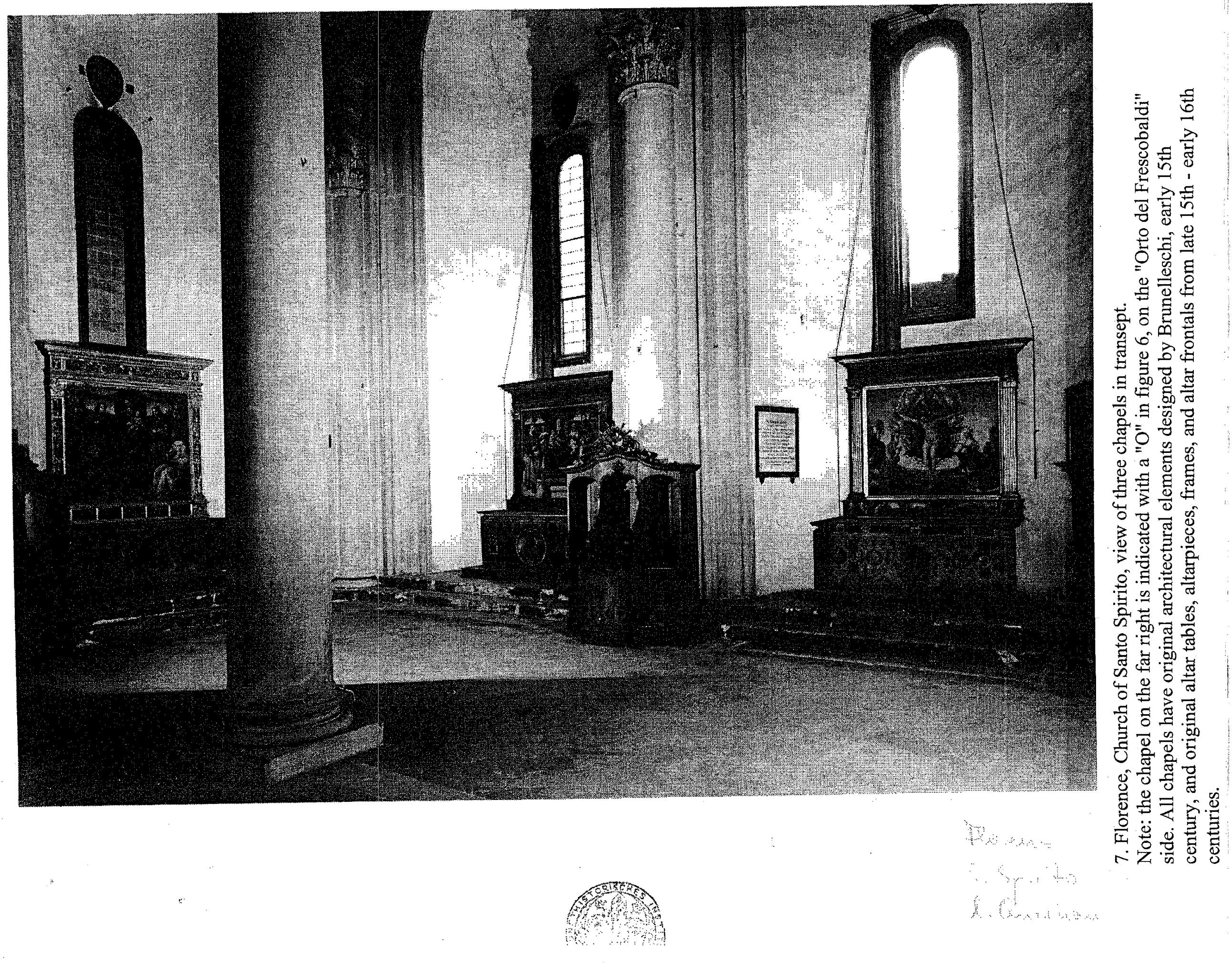


